\title{
37. ROCK- AND PALEOMAGNETISM OF LEG 43 BASALTS
}

\author{
N. Petersen, Institut für Allgemeine und Angewandte Geophysik, Ludwig-Maximilians Universität, München, \\ West Germany \\ U. Bleil, Institut für Geophysik, Ruhr-Universität, Bochum, West Germany \\ and \\ P. Eisenach, Institut für Allgemeine und Angewandte Geologie, Ludwig-Maximilians Universität, München, \\ West Germany
}

\section{INTRODUCTION}

Ten samples of basalt from Hole 384, four from Hole 386, and six from Hole 387 were analyzed for paleomagnetic and rock magnetic properties. The measurements were complemented by ore microscopic observation. The cored rocks are oriented only with respect to vertical, and so only the inclination of remanent magnetization can be given in absolute values.

\section{MAGNETIC MEASUREMENTS}

\section{Methods}

Remanent magnetization of the rocks was measured with a Digico spinner magnetometer. Stepwise alternating field demagnetization at $25,50,75,100,150,200$, $300,400,500$, and 1000 Oe was carried out in order to determine the stable direction of magnetization.

Volume susceptibility was measured with a Bison magnetic susceptibility bridge. From these values the Koenigsberger $Q$-ratio (natural remanent magnetization $[\mathrm{NRM}] \times$ induced magnetization $[\chi \cdot H]$, where $\chi$ is the susceptibility and $H$ the earth's magnetic field) was determined. The isothermal saturation remanent magnetization $\left(J_{s r}\right)$ was produced in a $10^{4} \mathrm{Oe}$ magnetic d.c. field. The coercivity $\left(H_{\mathrm{c}}\right)$ was determined by measuring the hysteresis loop (maximum field $10^{4} \mathrm{Oe}$ ); the coercivity of remanence $\left(H_{c r}\right)$ was determined by stepwise reduction of the saturation remanence in magnetic d.c. fields applied in opposite directions.

The Curie temperature $\left(T_{c}\right)$ was determined by measurement of the temperature dependence of the strong-field specific magnetization $I^{1800} \mathrm{Oe}$ with a magnetic balance (measured in air at an applied field strength of 1800 Oe). The specific magnetization $I^{1800 \mathrm{Oe}}$ is measured as magnetic moment per unit weight. If compared with $J$ (measured as magnetic moment per volume), it must be multiplied by the density of the rock.

\section{Results}

The results of the magnetic measurements are summarized in Tables 1, 2, and 3. Figures 1(A,B), 2, and 3 show typical thermomagnetic curves.

All samples show relatively high Curie temperatures, mostly higher than $400^{\circ} \mathrm{C}$. In comparison, the mean Curie temperature of unaltered Leg 37 basalts is $119^{\circ} \mathrm{C}$ (Bleil and Petersen, 1977). This difference can most reasonably be explained by subsequent alteration of the magnetic minerals; that is, high- or low-temperature oxidation, or a superposition of both. With the exception of Samples 384-22-CC, 9-11 cm, and 384-22CC, $46-48 \mathrm{~cm}$, the thermomagnetic curves of all other samples are distinctly irreversible, as is typical when the low-temperature oxidation product maghemite is present. Figure 1(B) illustrates this phenomenon most clearly.

The ratio of saturation remanent magnetization $\left(J_{s r}\right)$ and strong field magnetization $\left(I^{1800 \mathrm{Oe}}{ }_{20}^{\circ} \mathrm{C} \times\right.$ density of the rock) does not exceed 0.2 and has a mean value of 0.1 . As the strong-field magnetization measured in 1800 Oe at room temperature is in first order approximation to the saturation magnetization, these low values suggest multidomain particles to be the dominant carrier of the remanent magnetization. In this context, it is interesting to note the relatively large grain sizes of the titanomagnetites (see Tables 4, 5, 6).

\section{ORE MICROSCOPIC INVESTIGATION}

\section{Method}

Polished sections of the samples were examined under the ore microscope using a Leitz Ortholux Pol microscope. Magnetic colloid was used as an aid in the identification of the magnetic minerals.

\section{Results}

\section{Site 384}

A brief description of each sample is given in Table 7. All samples are amygdaloidal phyric basalt in different states of alteration.

Samples 22-1, 118-120 cm (Figures 4 and 5), 22-2, 14-16 cm; and 22-2, 35-37 cm (Figures 6 and 7) are dark gray basalt with abundant subrounded vesicles generally filled with green chlorite. The large skeletal to anhedral titanomagnetites show ilmenite exsolution lamellae and, less commonly, small hematite bodies (deuteric oxidation class 4). Partial maghematization indicates additional subsequent low temperature oxidation (see Figures 4 and 5). There is a remarkable amount of isolated primary ilmenite, which may be as abundant as or more abundant than titanomagnetite.

Samples 22-2, 56-58 cm, and 22-2, 64-66 cm are of a slightly red-brown basalt. They seem to form a tran- 
sition zone with more elliptical amygdules and veinlets of iron hydroxide. The oxidation state of the opaque minerals and the content of disseminated hematite exceeds that of the overlying basalt.

Samples 22-2, 80-82 cm; 22-2, 106-108 cm; and 22$2,127-129 \mathrm{~cm}$ are red-brown, with calcite-filled amyg- dules. The oxidation of titanomagnetite has proceeded over ilmenite exsolution lamellae and hematite to iron hydroxide. Even ilmenite is commonly replaced by iron hydroxide. Red staining of the silicate groundmass around the opaque minerals indicates the high oxidation state of these samples.

TABLE 1

Magnetic Parameters of Site 384 Basalts

\begin{tabular}{|c|c|c|c|c|c|c|c|c|c|c|c|}
\hline $\begin{array}{c}\text { Sample } \\
\text { (Interval in } \mathrm{cm} \text { ) }\end{array}$ & $\begin{array}{r}\text { NRM } \\
\text { Intensity } \\
\left(10^{-3} \text { Gauss }\right)\end{array}$ & $\begin{array}{c}\text { Incl. } \\
\left(^{\circ}\right)\end{array}$ & $\begin{array}{l}\text { Stable } \\
\text { Incl. }\left(^{\circ}\right)\end{array}$ & $\begin{array}{l}\text { Susceptibility } \\
\left(10^{-3} \text { Gauss/oe }\right)\end{array}$ & $Q$ & $\begin{array}{l}\text { MDF } \\
\text { (oe) }\end{array}$ & $\begin{array}{l}H_{c} \\
(\mathrm{oe})\end{array}$ & $\begin{array}{l}H_{c r} \\
(\mathrm{oe})\end{array}$ & $\begin{array}{c}J_{S r} \\
\text { (Gauss) }\end{array}$ & $\begin{array}{c}T_{C} \\
\left({ }^{\circ} \mathrm{C}\right)\end{array}$ & $\begin{array}{c}1800 \text { oe } \\
I 20^{\circ} \mathrm{C} \\
\left(\mathrm{Gauss}^{\circ} \mathrm{cm}^{3} / \mathrm{g}\right)\end{array}$ \\
\hline $22-1,118-120$ & 2.927 & 17.5 & 76.6 & 1.650 & 3.23 & 58 & 88 & 160 & 0.238 & $\begin{array}{l}340 ? \\
585\end{array}$ & 0.675 \\
\hline $\begin{array}{l}22-2,14-16 \\
22-2,35-37 \\
22-2,56-58 \\
22-2,64-66 \\
22-2,80-82 \\
22-2,106-108\end{array}$ & $\begin{array}{l}1.577 \\
1.143 \\
0.464 \\
0.402 \\
6.102 \\
2.434\end{array}$ & $\begin{array}{l}28.4 \\
73.3 \\
40.2 \\
40.1 \\
35.0 \\
51.2\end{array}$ & $\begin{array}{l}76.9 \\
69.4 \\
48.5 \\
52.9 \\
59.3 \\
58.8\end{array}$ & $\begin{array}{l}1.820 \\
1.214 \\
0.752 \\
0.821 \\
2.346 \\
1.975\end{array}$ & $\begin{array}{l}1.58 \\
1.71 \\
1.12 \\
0.89 \\
4.73 \\
2.24\end{array}$ & $\begin{array}{r}68 \\
251 \\
434 \\
465 \\
204 \\
195\end{array}$ & $\begin{array}{r}80 \\
212 \\
308 \\
228 \\
140 \\
120\end{array}$ & $\begin{array}{l}148 \\
360 \\
412 \\
520 \\
292 \\
264\end{array}$ & $\begin{array}{l}0.234 \\
0.374 \\
0.249 \\
0.180 \\
0.390 \\
0.233\end{array}$ & $\begin{array}{l}555 \\
550 \\
575 \\
550 \\
600 \\
385 ? \\
580\end{array}$ & $\begin{array}{l}0.43 \\
0.52 \\
0.483 \\
0.35 \\
0.30 \\
0.770\end{array}$ \\
\hline $\begin{array}{l}22-2,127-129 \\
22, C C, 104-111 \\
22, C C, 146-148\end{array}$ & $\begin{array}{l}1.670 \\
0.882 \\
4.096\end{array}$ & $\begin{array}{r}61.7 \\
-34.2 \\
-43.8\end{array}$ & $\begin{array}{r}60.4 \\
-35.0 \\
-38.7\end{array}$ & $\begin{array}{l}1.705 \\
0.533 \\
1.309\end{array}$ & $\begin{array}{l}1.78 \\
3.01 \\
5.69\end{array}$ & $\begin{array}{r}208 \\
>1000 \\
463\end{array}$ & $\begin{array}{r}112 \\
>600 \\
240\end{array}$ & $\begin{array}{l}256 \\
- \\
460\end{array}$ & $\begin{array}{l}0.202 \\
0.503 \\
0.305\end{array}$ & $\begin{array}{l}600 \\
180 / 600 \\
550\end{array}$ & $\begin{array}{l}0.55 \\
0.359 \\
0.540\end{array}$ \\
\hline $\begin{array}{l}\text { Mean Values } \\
\text { Standard } \\
\text { Deviation }\end{array}$ & $\begin{array}{r}2.169 \\
\pm 1.800\end{array}$ & - & $\begin{array}{l}\text { pos. incl } \\
62.8 \\
\pm 10.5 \\
\text { neg. incl } \\
-36.8 \\
\pm 2.6\end{array}$ & $\begin{array}{r}1.413 \\
\pm 0.587\end{array}$ & $\begin{array}{r}2.6 \\
\pm 1.6\end{array}$ & - & - & - & $\begin{array}{r}0.290 \\
\pm 0.102\end{array}$ & - & $\begin{array}{r}0.558 \\
\pm 0.177\end{array}$ \\
\hline
\end{tabular}

TABLE 2

Magnetic Parameters of Site 386 Basalts

\begin{tabular}{|c|c|c|c|c|c|c|c|c|c|c|c|}
\hline Sample & $\begin{array}{r}\text { NRM } \\
\text { Intensity } \\
\left(10^{-3} \text { Gauss }\right)\end{array}$ & $\begin{array}{l}\text { Incl. } \\
\left({ }^{\circ}\right)\end{array}$ & $\begin{array}{l}\text { Stable } \\
\text { Incl. }\left({ }^{\circ}\right)\end{array}$ & $\begin{array}{l}\text { Susceptibility } \\
\left(10^{-3} \text { Gauss/oe) }\right.\end{array}$ & $Q$ & $\begin{array}{l}\text { MDF } \\
\text { (oe) }\end{array}$ & $\begin{array}{l}H_{c} \\
\text { (oe) }\end{array}$ & $\begin{array}{l}\mathrm{H}_{c r} \\
\text { (oe) }\end{array}$ & $\begin{array}{c}J_{s r} \\
\text { (Gauss) }\end{array}$ & $\begin{array}{l}T_{C} \\
\left({ }^{\circ} \mathrm{C}\right)\end{array}$ & $\begin{array}{c}1800 \text { oe } \\
I 20^{\circ} \mathrm{C} \\
\left(\mathrm{Gauss} \cdot \mathrm{cm}^{3} / \mathrm{g}\right)\end{array}$ \\
\hline 66-1 (1) & 3.936 & 37.6 & 49.1 & 2.239 & 3.20 & 95 & 84 & 172 & 0.217 & 360 & 0.60 \\
\hline $66-2(14)$ & 0.643 & 54.8 & 60.8 & 0.513 & 2.28 & 122 & 76 & 176 & 0.042 & $\begin{array}{l}390 ? \\
490\end{array}$ & 0.113 \\
\hline $\begin{array}{l}66-2(21) \\
66, C C(3)\end{array}$ & $\begin{array}{l}2.9 \\
3.590\end{array}$ & $\begin{array}{r}62.4 \\
-66.5\end{array}$ & $\begin{array}{r}62.8 \\
-55.6\end{array}$ & $\begin{array}{l}0.056 \\
3.103\end{array}$ & $\begin{array}{l}0.09 \\
2.10\end{array}$ & $\begin{array}{r}197 \\
51\end{array}$ & $\overline{48}$ & $1 \overline{00}$ & $\begin{array}{l}1.1610^{-3} \\
0.245\end{array}$ & 345 & $\begin{array}{l}0.013 \\
0.872\end{array}$ \\
\hline $\begin{array}{l}\text { Mean Values } \\
\text { Standard } \\
\text { Deviation }\end{array}$ & $\begin{array}{r}2.043 \\
\pm 2.008\end{array}$ & - & $\begin{array}{l}57.1 \\
\pm 6.2\end{array}$ & $\begin{array}{r}1.478 \\
\pm 1.434\end{array}$ & $\begin{array}{r}1.9 \\
\pm 1.3\end{array}$ & $\begin{array}{l}116 \\
\pm 61\end{array}$ & - & - & $\begin{array}{r}0.126 \\
\pm 0.123\end{array}$ & $\begin{array}{l}372 \\
\pm 34\end{array}$ & $\begin{array}{r}0.399 \\
\pm 0.407\end{array}$ \\
\hline
\end{tabular}

TABLE 3

Magnetic Parameters of Site 387 Basalts

\begin{tabular}{|c|c|c|c|c|c|c|c|c|c|c|c|}
\hline \multirow[b]{2}{*}{$\begin{array}{c}\text { Sample } \\
\text { (Interval in } \mathrm{cm} \text { ) }\end{array}$} & \multicolumn{2}{|l|}{ NRM } & \multirow[b]{2}{*}{$\begin{array}{l}\text { Stable } \\
\text { Incl. }\left({ }^{\circ}\right)\end{array}$} & \multirow[b]{2}{*}{$\begin{array}{l}\text { Susceptibility } \\
\left(10^{-3} \text { Gauss/oe }\right)\end{array}$} & \multirow[b]{2}{*}{$Q$} & \multirow[b]{2}{*}{$\begin{array}{l}\text { MDF } \\
(\mathrm{oe})\end{array}$} & \multirow[b]{2}{*}{$\begin{array}{l}H_{c} \\
(\mathrm{oe})\end{array}$} & \multirow[b]{2}{*}{$\begin{array}{l}H_{c r} \\
(\mathrm{oe})\end{array}$} & \multirow[b]{2}{*}{$\begin{array}{c}J_{s r} \\
\text { (Gauss) }\end{array}$} & \multirow[b]{2}{*}{$\begin{array}{l}T_{c} \\
\left({ }^{\circ} \mathrm{C}\right)\end{array}$} & \multirow[b]{2}{*}{$\begin{array}{c}1800 \mathrm{oe} \\
I_{20^{\circ} \mathrm{C}} \\
\left(\mathrm{Gauss} \cdot \mathrm{cm}^{3} / \mathrm{g}\right)\end{array}$} \\
\hline & $\begin{array}{c}\text { Intensity } \\
\left(10^{-3} \text { Gauss }\right)\end{array}$ & $\begin{array}{c}\text { Incl. } \\
\left({ }^{\circ}\right)\end{array}$ & & & & & & & & & \\
\hline $50-1,22-25$ & 1.347 & 33.5 & 48.8 & 4.512 & 0.54 & 50 & 36 & 84 & 0.240 & 380 & 1.10 \\
\hline $50-1,35-38$ & 0.949 & 38.6 & 53.3 & 4.390 & 0.39 & 39 & 32 & 92 & 0.172 & 370 & 1.05 \\
\hline $50-1,98-101$ & 3.237 & 60.2 & 67.0 & 3.321 & 1.77 & 101 & 68 & 132 & 0.314 & 420 & 0.955 \\
\hline $50-2,30-33$ & 4.050 & $-52.2 ?$ & $-58.0 ?$ & 3.737 & 1.97 & 105 & 76 & 148 & 0.349 & 380 & 0.90 \\
\hline $50-2,48-51$ & 4.188 & 66.4 & 66.3 & 2.821 & 2.70 & 147 & 92 & 184 & 0.352 & 340 & 0.77 \\
\hline $50-2,134-137$ & 2.624 & $-61.5 ?$ & $-59.2 ?$ & 3.858 & 1.24 & 80 & 60 & 124 & 0.295 & 370 & 1.30 \\
\hline Mean Values & 2.733 & - & 58.8 & 3.733 & 1.4 & 87 & 60 & 127 & 0.287 & 385 & 0.946 \\
\hline $\begin{array}{l}\text { Standard } \\
\text { Deviation }\end{array}$ & \pm 1.358 & & \pm 7.1 & \pm 0.640 & \pm 0.9 & \pm 40 & \pm 23 & \pm 37 & \pm 0.070 & \pm 79 & \pm 0.118 \\
\hline
\end{tabular}



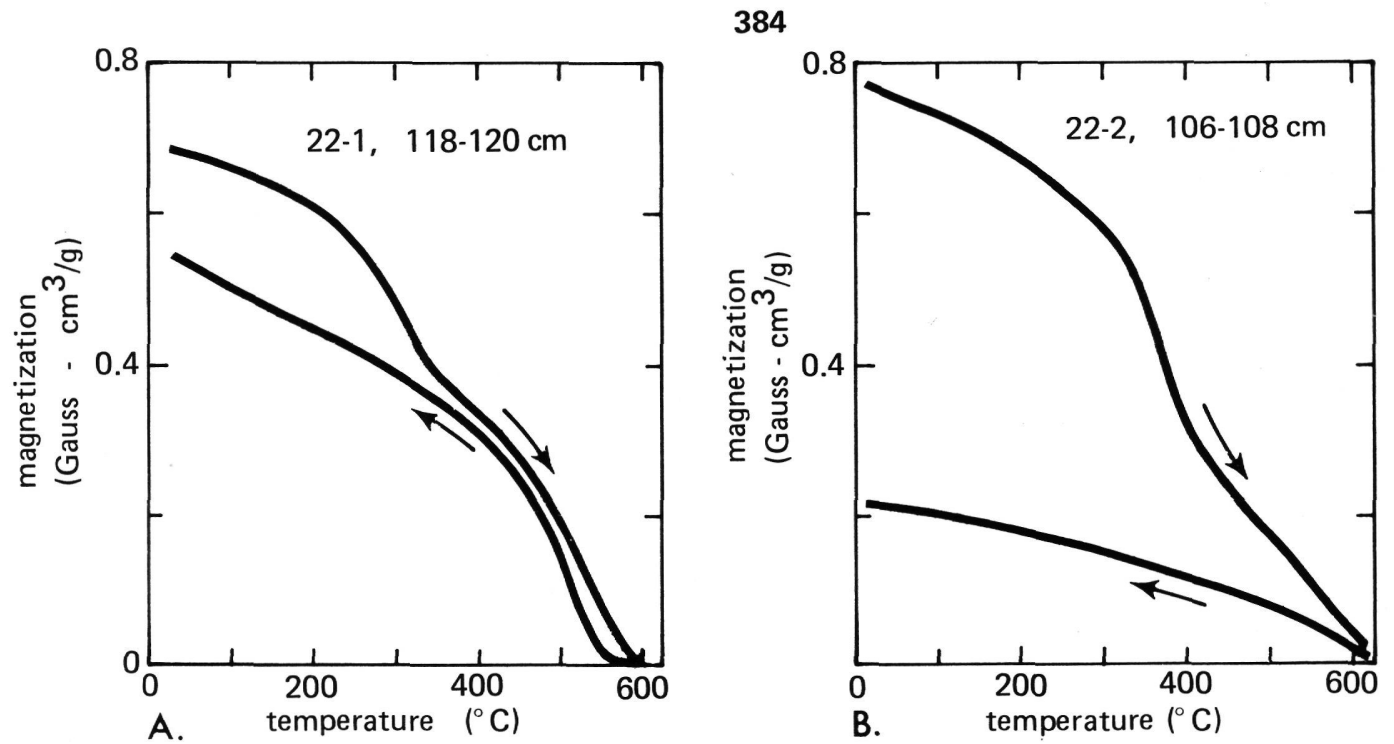

Figure 1. (A and B) Thermomagnetic curves, measured in air (magnetic field 1800 oe). The irreversibility of heating and cooling curves is indicative of maghemite as main carrier of magnetization.

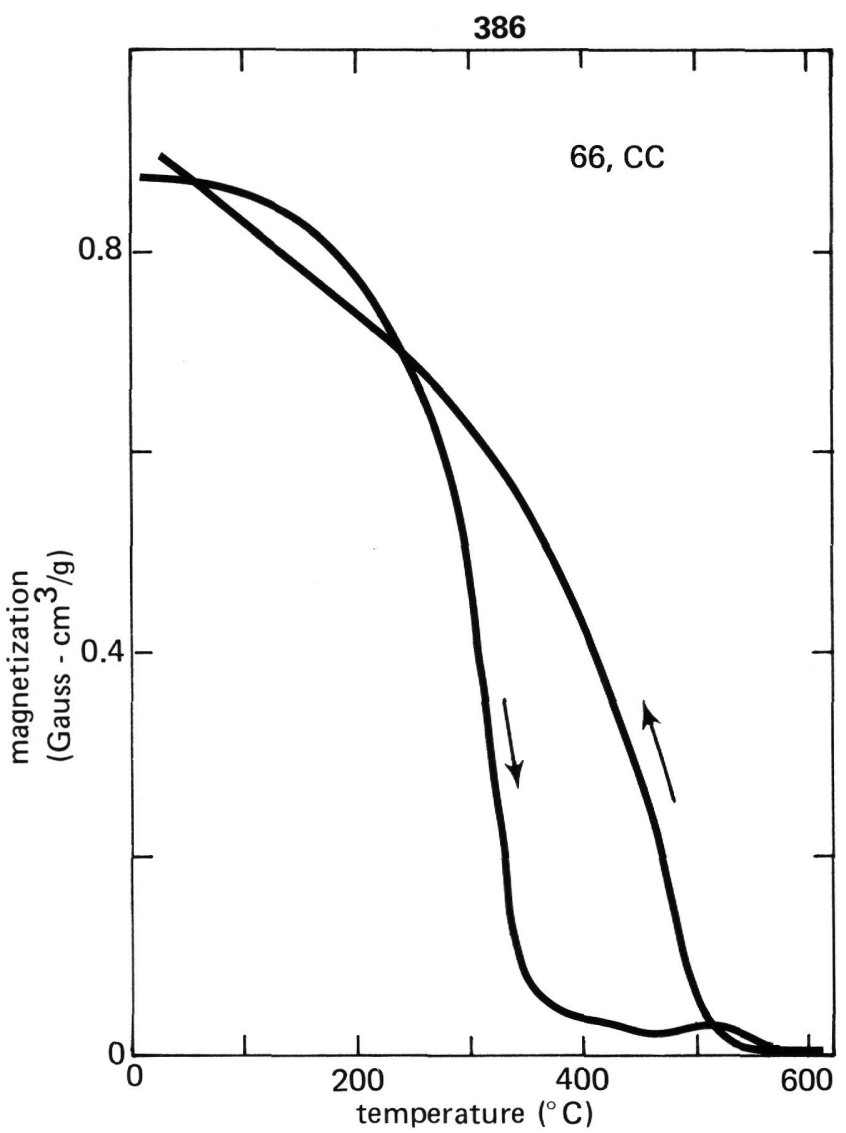

Figure 2. Thermomagnetic curve, measured in air (magnetic field 1800 oe).

Basalts of samples 22-CC, 9-11 cm; and 22-CC, 46$48 \mathrm{~cm}$ are less altered than the above.

Sulfides are rare in all investigated samples from Site 384. The superposition of deuteric high-tempera-

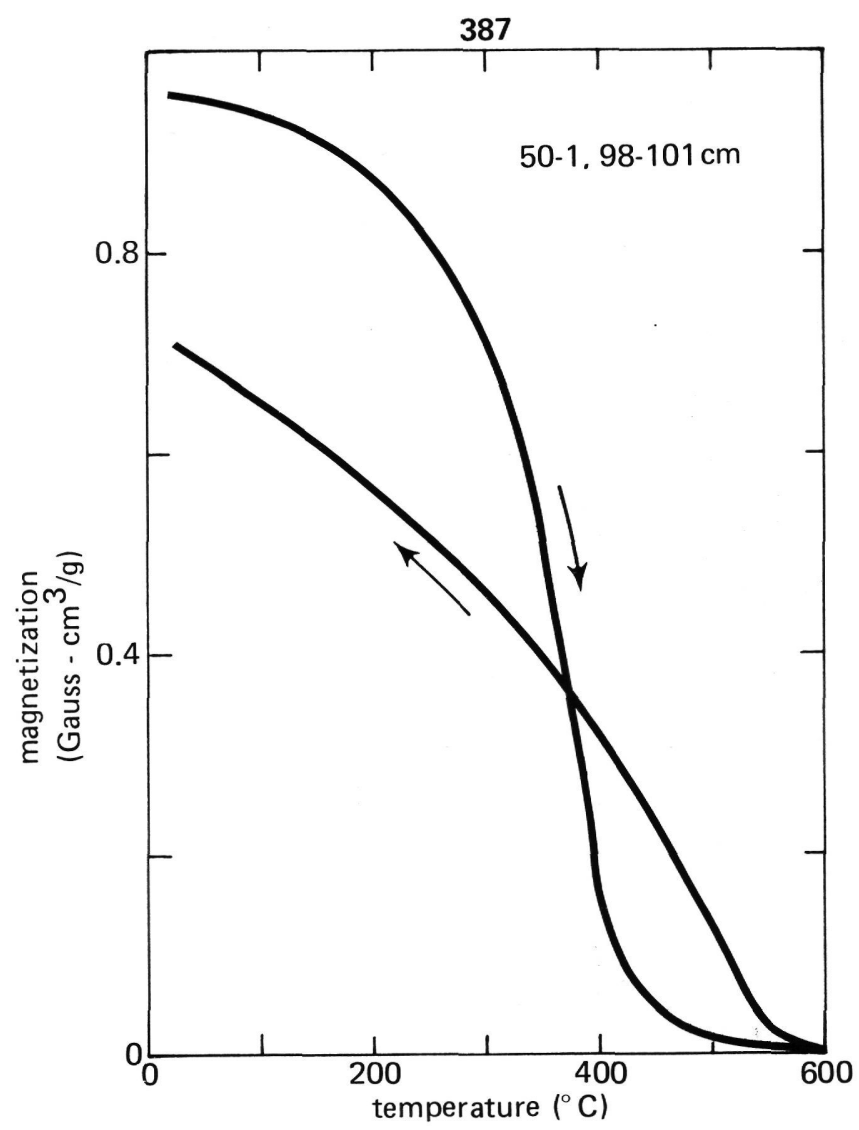

Figure 3. Thermomagnetic curve, measured in air (magnetic field 1800 oe).

ture oxidation and low-temperature oxidation suggests a complicated thermal history. The large-sized chromites may have formed before eruption under low oxygen pressure. 
TABLE 4

Mean Grain Diameter in Microns of the Different Ore Phases in the Site 384 Basalts

\begin{tabular}{lccc}
\hline $\begin{array}{c}\text { Sample } \\
\text { (Interval in cm) }\end{array}$ & Titanomagnetite & Ilmenite & Chromite \\
\hline $22-1,118-120$ & 31 & 27 & 105 \\
$22-2,14-16$ & 20 & 20 & 35 \\
$22-2,35-37$ & 35 & 30 & 100 \\
$22-2,56-58$ & 45 & 30 & 45 \\
$22-2,64-66$ & 30 & 20 & 30 \\
$22-2,80-82$ & 15 & 10 & 90 \\
$22-2,106-108$ & 30 & 20 & - \\
$22-2,127-129$ & 20 & 20 & 105 \\
$22-C C, 109-111$ & 25 & 15 & 25 \\
$22-C C, 146-148$ & 40 & 40 & - \\
\hline
\end{tabular}

TABLE 5

Mean Grain Diameter in Microns of the Different Ore Phases in the Site 386 Basalts

\begin{tabular}{lccc}
\hline Sample & Titanomagnetite & Ilmenite & Chromite \\
\hline $66-2(14)$ & $<5$ & - & - \\
$66-2(21)$ & $<5$ & - & - \\
66, CC $(3)$ & 30 & - & - \\
\hline
\end{tabular}

TABLE 6

Mean Grain Diameter in Microns of the Different Ore Phases in the Site 387 Basalts

\begin{tabular}{lccc}
\hline $\begin{array}{c}\text { Sample } \\
\text { (Interval in cm) }\end{array}$ & Titanomagnetite & Ilmenite & Chromite \\
\hline $50-1,22-25$ & 20 & - & - \\
$50-1,35-38$ & 10 & - & - \\
$50-1,98-101$ & 10 & - & - \\
$50-2,30-33$ & 5 & - & - \\
$50-2,134-137$ & 20 & - & - \\
\hline
\end{tabular}

The deuteric high-temperature oxidation (oxidation class 3) may be an indication of crystallization under subaerial or shallow-water conditions. Similar observations have been made for Leg 38 basalts (Norwegian Sea) from Sites 336, 338, and 342 by Kent and Opdyke (1976), and for Leg 26 basalts (Ninety east Ridge) from Sites 253 and 254 by Ade-Hall (1974).

\section{Site 386}

A brief description of each individual sample is given in Table 8. Samples 66-23 (4) and 66-2 (21) are material from a hydrothermal vein that cuts the moderately chloritized basalt. The opaque phase of extremely fine grain size is typical for these rocks. Ore phases are too small to be analyzed more closely.

Sample 66, CC (3) is a coarser grained phyric basalt with ophitic texture. The small skeletal grains of titanomagnetite seem to be quite homogeneous and little altered.

\section{Site 387}

A brief description of each individual sample is given in Table 9. All samples are fine-grained amygdaloidal phyric basalt with skeletal to anhedral titano-

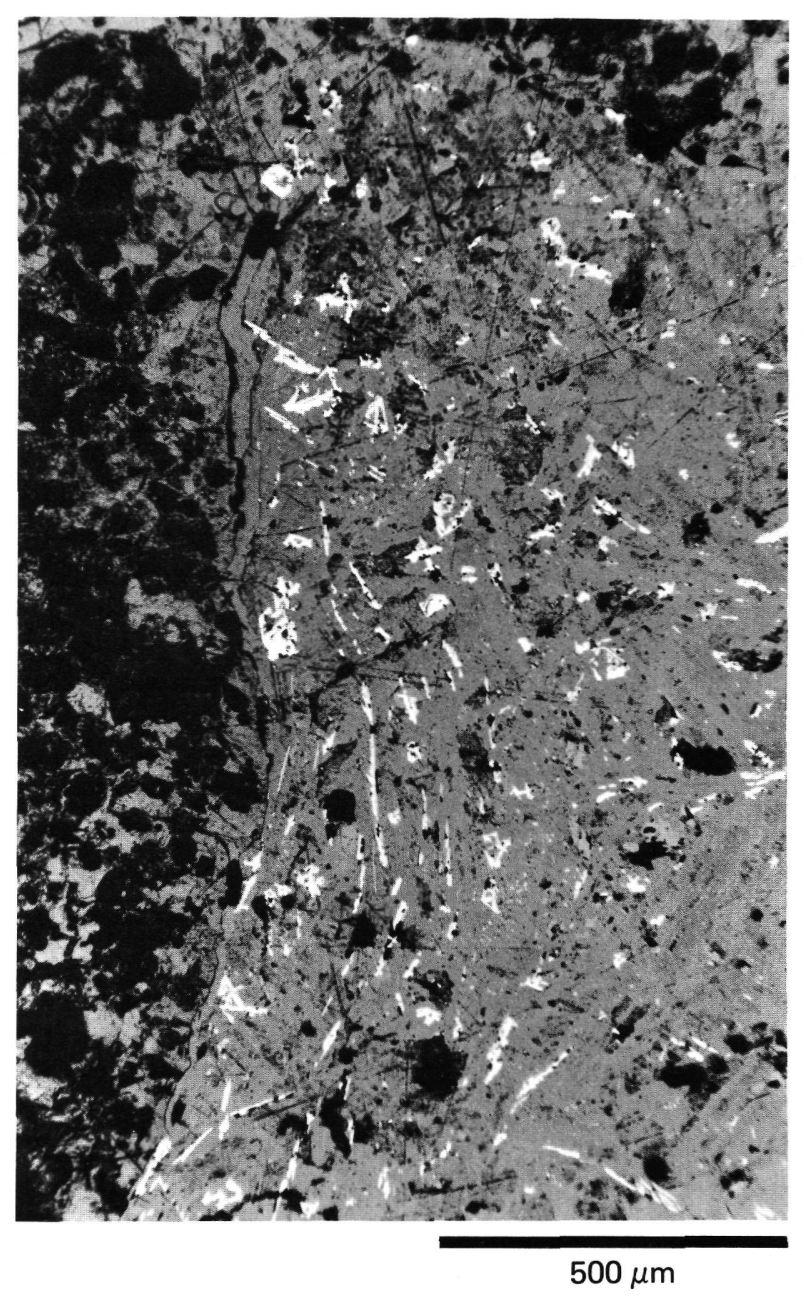

Figure 4. Fine grained amygdaloidal basalt showing minor fluction of plagioclase and ilmenite around the amygdules. Sample 22-1, 118-120 cm.

magnetite grains. The titanomagnetites seem to be fairly unaltered which is in contradiction to the thermomagnetic curves. Ilmenite and chromite are absent.

\section{SUMMARY AND DISCUSSION}

The carriers of remanent magnetization in the investigated samples are grains of titanomagnetite. There may also be some negligible contribution from sulfides and chromites.

\section{Site 384}

High-temperature deuteric oxidation of the titanomagnetites is overprinted by later low-temperature oxidation. Low-temperature oxidation of titanomagnetites is typical for deep ocean weathering (halmyrolysis). In contrast to subaerial basalts, high-temperature oxidation of titanomagnetites seems to be rare in ocean-floor basalts (Ade-Hall et al., 1976) and may only occur in the center of massive flows (Watkins and Haggerty, 1967; Grommé et al., 1969).

Two distinctly different groups of stable magnetization inclination directions were observed: relatively 
TABLE 7

Ore Microscopic Description of Site 384 Basalts

\begin{tabular}{|c|c|c|c|c|c|}
\hline \multirow{2}{*}{$\begin{array}{l}\text { Sample } \\
\text { (Interval in cm) }\end{array}$} & \multirow[b]{2}{*}{ General Petrography } & \multirow[b]{2}{*}{ Titanomagnetite } & \multicolumn{2}{|c|}{ Ore Phases } & \multirow[b]{2}{*}{ Other Phases } \\
\hline & & & Ilmenite & Chromite & \\
\hline $22-1,118-120$ & $\begin{array}{l}\text { Fine-grained amygdaloidal phyric } \\
\text { basalt with varying texture, often } \\
\text { showing minor fluxion of } \\
\text { plagioclase- and ilmenite laths } \\
\text { around the amygdules; commonly } \\
\text { ore phase is more abundant in } \\
\text { higher reflecting rims around } \\
\text { amygdules; basalt is quite vesicular } \\
\text { (Fig. } 1 \text { and } 2 \text { ) }\end{array}$ & $\begin{array}{l}\text { Skeletal to anhedral grains, } \\
\text { from relatively large size down } \\
\text { to the limit of visibility; some- } \\
\text { times rimmed by hematite, } \\
\text { sometimes mottled, with oxida- } \\
\text { tion to titanomaghemite? }\end{array}$ & $\begin{array}{l}\text { Abundant isolated } \\
\text { laths; most grains } \\
\text { show signs of oxida- } \\
\text { tion; grains some- } \\
\text { times mantled by } \\
\text { titanomagnetite }\end{array}$ & $\begin{array}{l}\text { Large euhedral } \\
\text { grains, either } \\
\text { homogeneous or } \\
\text { with a dark } \mathrm{Al}- \\
\text { rich core and an } \\
\text { outer Fe-rich } \\
\text { lighter and often } \\
\text { porous zone }\end{array}$ & $\begin{array}{l}\text { Fine-grained hematite } \\
\text { fringes around titano- } \\
\text { magnetite; rare extremely } \\
\text { fine grains of sulfide }\end{array}$ \\
\hline $22-2,14-16$ & $\begin{array}{l}\text { Amygdaloidal phyric basalt with } \\
\text { rare phenocrysts; quite vesicular } \\
\text { (Fig. 3) }\end{array}$ & $\begin{array}{l}\text { Skeletal to anhedral, some- } \\
\text { times with patches of titano- } \\
\text { maghemite; grains sometimes } \\
\text { contain ilmenite lamellae, not } \\
\text { always in definite crystallo- } \\
\text { graphic directions (deuteric } \\
\text { oxidation?); fringes of fine- } \\
\text { grained hematite }\end{array}$ & $\begin{array}{l}\text { Abundant primary } \\
\text { ilmenite, mostly } \\
\text { with signs of oxida- } \\
\text { tion; slight red stain- } \\
\text { ing of groundmass } \\
\text { adjacent to ilmenite; } \\
\text { ilmenite more } \\
\text { abundant than } \\
\text { titanomagnetite }\end{array}$ & $\begin{array}{l}\text { Large euhedral to } \\
\text { anhedral grains, } \\
\text { homogeneous or } \\
\text { mottled and } \\
\text { porous }\end{array}$ & $\begin{array}{l}\text { Extremely small hematite } \\
\text { grains }\end{array}$ \\
\hline $22-2,35-37$ & $\begin{array}{l}\text { Amygdaloidal phyric basalt similar } \\
\text { to } 22-1,118-120 \mathrm{~cm} \text {, but no rims } \\
\text { of higher reflectivity around } \\
\text { amygdules (Fig. } 4 \mathrm{a} \text { and } \mathrm{b} \text { ) }\end{array}$ & $\begin{array}{l}\text { Two generations, large skeletal } \\
\text { to anhedral grains and small } \\
\text { skeletal grains; the former are } \\
\text { altered with patches of titano- } \\
\text { maghemite and lamellae of } \\
\text { ilmenite; hematite fills cracks } \\
\text { and forms fringes, of ten re- } \\
\text { placed by iron hydroxide; red } \\
\text { staining of the adjacent } \\
\text { silicates; smaller generation } \\
\text { ti.mag. looks homogeneous } \\
\text { without signs of oxidation }\end{array}$ & $\begin{array}{l}\text { Abundant isolated } \\
\text { subhedral laths, } \\
\text { altered with patches } \\
\text { of magnetite }\end{array}$ & $\begin{array}{l}\text { Large euhedral to } \\
\text { anhedral grains, } \\
\text { sometimes inter- } \\
\text { grown with } \\
\text { skeletal ti.mag; } \\
\text { mottled and } \\
\text { porous }\end{array}$ & Iron hydroxides \\
\hline $22-2,56-58$ & $\begin{array}{l}\text { Altered amygdaloidal phyric } \\
\text { basalt; amygdules are lined by a } \\
\text { broad seam of iron hydroxide }\end{array}$ & $\begin{array}{l}\text { Highly altered skeletal to } \\
\text { anhedral grains with ilmenite } \\
\text { lamellae (deuteric oxidation?) } \\
\text { and disseminated hematite or } \\
\text { iron hydroxide; some grains } \\
\text { completely replaced by iron } \\
\text { hydroxide; red staining of } \\
\text { groundmass around ore grains }\end{array}$ & $\begin{array}{l}\text { Altered isolated } \\
\text { laths, partly with } \\
\text { patches of } \\
\text { magnetite }\end{array}$ & $\begin{array}{l}\text { Few large } \\
\text { euhedral grains } \\
\text { with dark core }\end{array}$ & $\begin{array}{l}\text { Abundant iron hydroxide } \\
\text { in the amygdules and also } \\
\text { partly replacing titanomag- } \\
\text { netite }\end{array}$ \\
\hline $22-2,64-66$ & $\begin{array}{l}\text { Amygdaloidal phyric basalt with } \\
\text { increasing content of calcite }\end{array}$ & $\begin{array}{l}\text { Altered skeletal to anhedral } \\
\text { grains containing ilmenite } \\
\text { lamellae (deuteric oxidation?) } \\
\text { red staining of adjacent } \\
\text { silicates; some grains replaced } \\
\text { by iron hydroxide }\end{array}$ & $\begin{array}{l}\text { Isolated laths, } \\
\text { marginally oxidized } \\
\text { to magnetite }\end{array}$ & $\begin{array}{l}\text { Like } 22-1,118- \\
120 \mathrm{~cm} ; \text { more } \\
\text { frequent adjacent } \\
\text { to amygdules }\end{array}$ & Iron hydroxide \\
\hline $22-2,80-82$ & $\begin{array}{l}\text { Amygdaloidal phyric basalt similar } \\
\text { to } 22-1,118-120 \mathrm{~cm} \text {; red staining } \\
\text { of groundmass close to opaque } \\
\text { minerals }\end{array}$ & $\begin{array}{l}\text { Highly altered small skeletal } \\
\text { grains, partly with ilmenite- } \\
\text { magnetite exsolution (deuteric } \\
\text { oxidation) magnetite of ten } \\
\text { being replaced by hematite; } \\
\text { sometimes replaced by iron } \\
\text { hydroxide }\end{array}$ & $\begin{array}{l}\text { Less and small iso- } \\
\text { lated laths, highly } \\
\text { altered, disseminated } \\
\text { by hematite and } \\
\text { iron hydroxide }\end{array}$ & $\begin{array}{l}\text { Large euhedral } \\
\text { grains with rims } \\
\text { of magnetite, } \\
\text { partly replaced } \\
\text { by iron } \\
\text { hydroxide }\end{array}$ & Abundant iron hydroxide \\
\hline $22-2,106-108$ & $\begin{array}{l}\text { Amygdaloidal phyric basalt with } \\
\text { texture similar to } 22-1,118-120 \\
\mathrm{~cm} \text {; red staining of groundmass } \\
\text { around Fe-Ti oxides }\end{array}$ & $\begin{array}{l}\text { Small skeletal to anhedral } \\
\text { grains, highly altered; exsolved } \\
\text { ilmenite lamellae replaced by } \\
\text { iron hydroxide; spinel exsolu- } \\
\text { tion }\end{array}$ & $\begin{array}{l}\text { Rare, highly altered } \\
\text { isolated laths, mar- } \\
\text { ginally replaced by } \\
\text { iron hydroxide }\end{array}$ & $\begin{array}{l}\text { Euhedral to } \\
\text { anhedral grains, } \\
\text { some mottled } \\
\text { and porous, some } \\
\text { homogeneous }\end{array}$ & Abundant iron hydroxide \\
\hline $22-2,127-129$ & $\begin{array}{l}\text { Amygdaloidal phyric basalt with } \\
\text { calcite veins; red staining of silicate } \\
\text { groundmass around opaque } \\
\text { minerals }\end{array}$ & Like $22-2,106-108 \mathrm{~cm}$ & $\begin{array}{l}\text { Similar to } 22-2, \\
106-108 \mathrm{~cm} \text {, but } \\
\text { slightly less oxidized }\end{array}$ & $\begin{array}{l}\text { Euhedral to } \\
\text { anhedral grains, } \\
\text { sometimes } \\
\text { mantled by ti- } \\
\text { tanomagnetite } \\
\text { containing } \\
\text { secondary exsolu- } \\
\text { tion lamellae }\end{array}$ & Abundant iron hydroxide \\
\hline 22-CC, $109-111$ & $\begin{array}{l}\text { Amygdaloidal phyric basalt; red } \\
\text { staining of groundmass around } \\
\text { opaque minerals }\end{array}$ & $\begin{array}{l}\text { Small skeletal grains with } \\
\text { ilmenite exsolution lamellae } \\
\text { (deuteric oxidation?) and very } \\
\text { fine disseminated hematite }\end{array}$ & $\begin{array}{l}\text { Small isolated laths, } \\
\text { sometimes with } \\
\text { signs of oxidation }\end{array}$ & $\begin{array}{l}\text { Large subhedral } \\
\text { grains, mottled } \\
\text { and porous }\end{array}$ & Not observed \\
\hline 22-CC, $146-148$ & $\begin{array}{l}\text { Amygdaloidal phyric basalt with } \\
\text { ophitic texture }\end{array}$ & $\begin{array}{l}\text { Skeletal grains with ilmenite } \\
\text { exsolution lamellae and very } \\
\text { fine disseminated hematite; } \\
\text { sometimes corroded with red } \\
\text { staining of adjacent silicate } \\
\text { groundmass }\end{array}$ & $\begin{array}{l}\text { Homogeneous laths, } \\
\text { sometimes mantled } \\
\text { by titanomagnetite; } \\
\text { beginning oxidation } \\
\text { with veinlets of } \\
\text { hematite on the } \\
\text { limit of visibility }\end{array}$ & $\begin{array}{l}\text { Subhedral to } \\
\text { anhedral grains, } \\
\text { mottled and } \\
\text { porous }\end{array}$ & $\begin{array}{l}\text { Iron hydroxides and } \\
\text { extremely fine grains of } \\
\text { sulfides }\end{array}$ \\
\hline
\end{tabular}




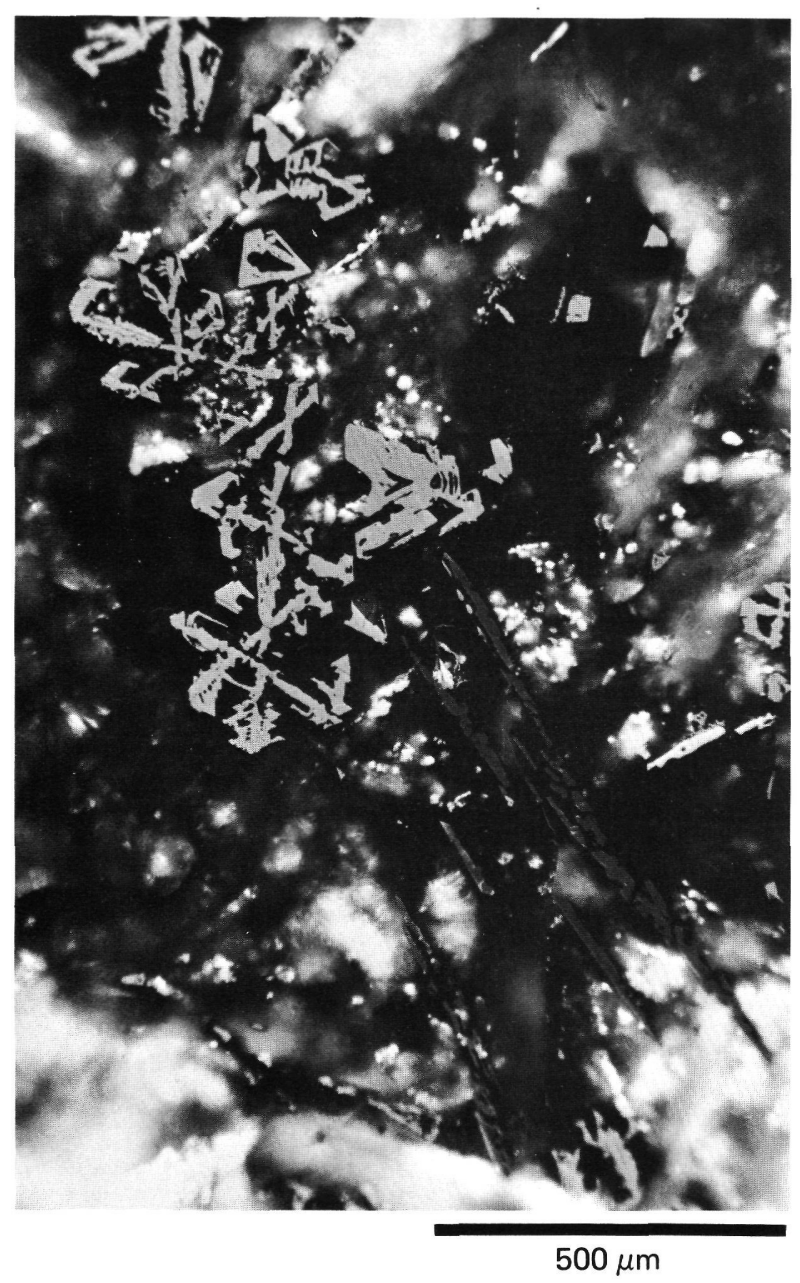

Figure 5. Skeletal titanomagnetite and large ilmenite laths. Sample 22-1, 118-120 cm.

steep (mean $62.8^{\circ}$ ) for the upper samples, and shallow (mean $-36.8^{\circ}$ ) for the two lowermost samples.

The present magnetic dipole field inclination at the latitude of Site 384 is $59.5^{\circ}$. If we assume a Cretaceous date for the measured basalts, the inclination to be expected at Site 384 is $41.8^{\circ}$ (taking a Cretaceous pole position for the North American plate of $64^{\circ} \mathrm{N}$, $173^{\circ} \mathrm{W}$; McElhinny, 1973). Comparing this inclination with the measured magnetization inclinations, we find reasonable agreement only for the shallow inclinations of the two lower samples. The steep inclination of the

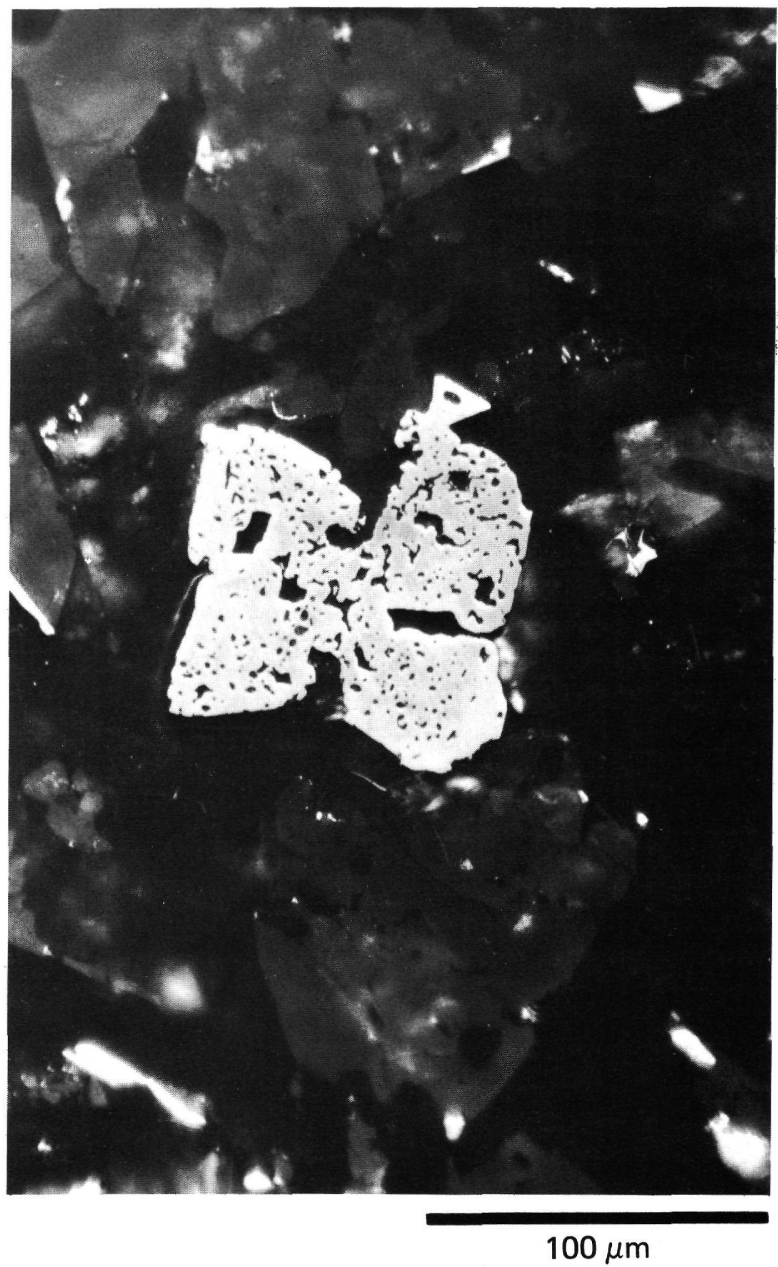

Figure 6. Large anhedral chromite pseudomorph to titanomagnetite (snowstar). Mottled dark gray porous core and a rim of titanomagnetite. Sample $22-2,14-16 \mathrm{~cm}$.

upper samples compares much better with the present geomagnetic dipole field of $59.5^{\circ}$.

Taking into account the rock magnetic data, we conclude that only the two lower samples, 22-CC, 109-111 $\mathrm{cm}$, and $22-\mathrm{CC}, 146-148 \mathrm{~cm}$, have retained their original thermoremanent magnetization. The other samples most likely have lost their primary magnetization owing to low-temperature oxidation of the magnetic minerals; the present remanent magnetization of these

TABLE 8

Ore Microscopic Description of Site 386 Basalts

\begin{tabular}{|c|c|c|c|c|c|}
\hline \multirow[b]{2}{*}{$\begin{array}{c}\text { Sample } \\
\text { (Interval in } \mathrm{cm} \text { ) }\end{array}$} & \multirow[b]{2}{*}{ General Petrography } & \multicolumn{4}{|c|}{ Ore Phases } \\
\hline & & Titanomagnetite & Ilmenite & Chromite & Other Phases \\
\hline $66-2(14)$ & - & $\begin{array}{l}\text { Extremely fine grained; too } \\
\text { fine for further microscopic } \\
\text { identification }\end{array}$ & $\begin{array}{l}\text { Extremely fine } \\
\text { grained }\end{array}$ & Not observed & \\
\hline $66-2(21)$ & - & Like $66-2(14)$ & Like 66-2 (14) & Not observed & Small sulfide grains \\
\hline $66, \mathrm{CC}(3)$ & $\begin{array}{l}\text { Coarser grained phyric basalt with } \\
\text { bulky texture of the plagioclase } \\
\text { laths }\end{array}$ & $\begin{array}{l}\text { Small skeletal grains which } \\
\text { look homogeneous and unal- } \\
\text { tered; sometimes intergrown } \\
\text { with sulfides }\end{array}$ & $\begin{array}{l}\text { Abundant isolated } \\
\text { unaltered laths }\end{array}$ & Not observed & $\begin{array}{l}\text { Sulfides of varying grain } \\
\text { size down to the limit of } \\
\text { visibility, partly intergrowth } \\
\text { of pyrite and bornite }\end{array}$ \\
\hline
\end{tabular}




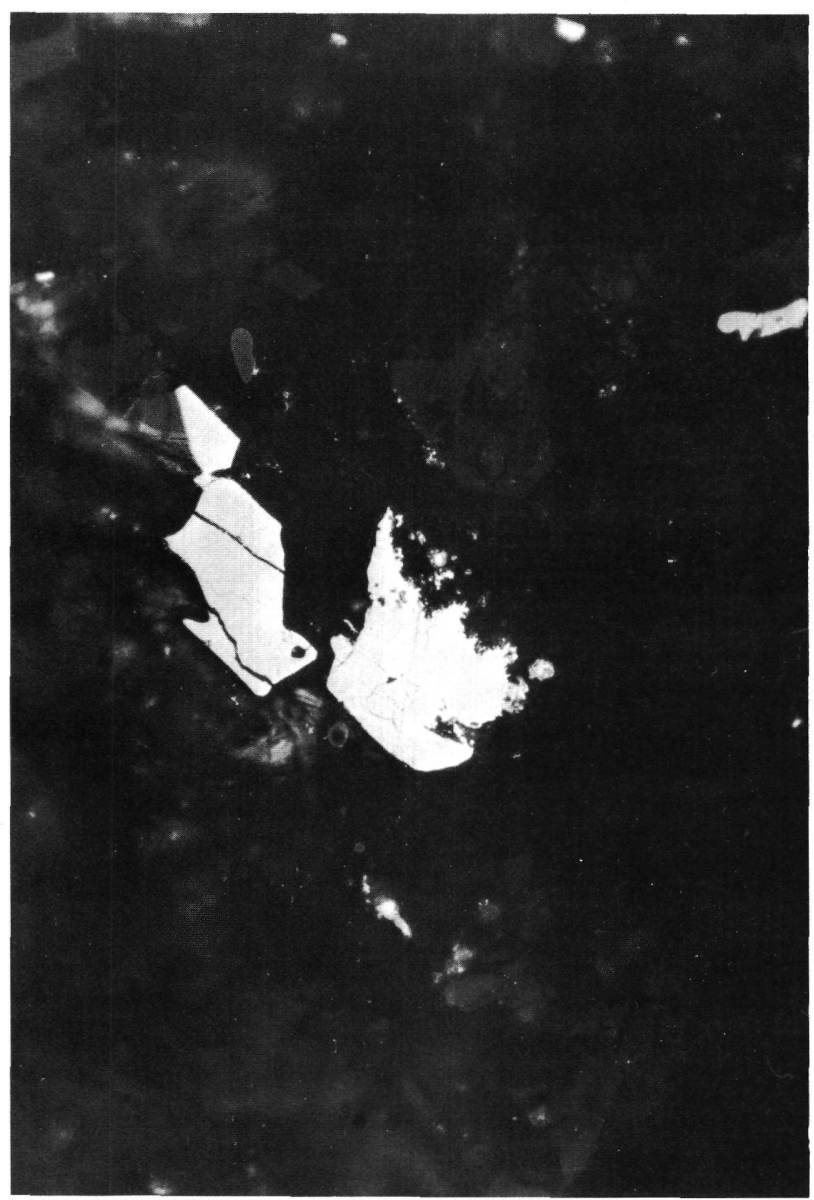

a.

$100 \mu \mathrm{m}$

Figure 7a. Homogeneous titanomagnetite without sign of oxidation. Sample 22-2, 35-38 cm.

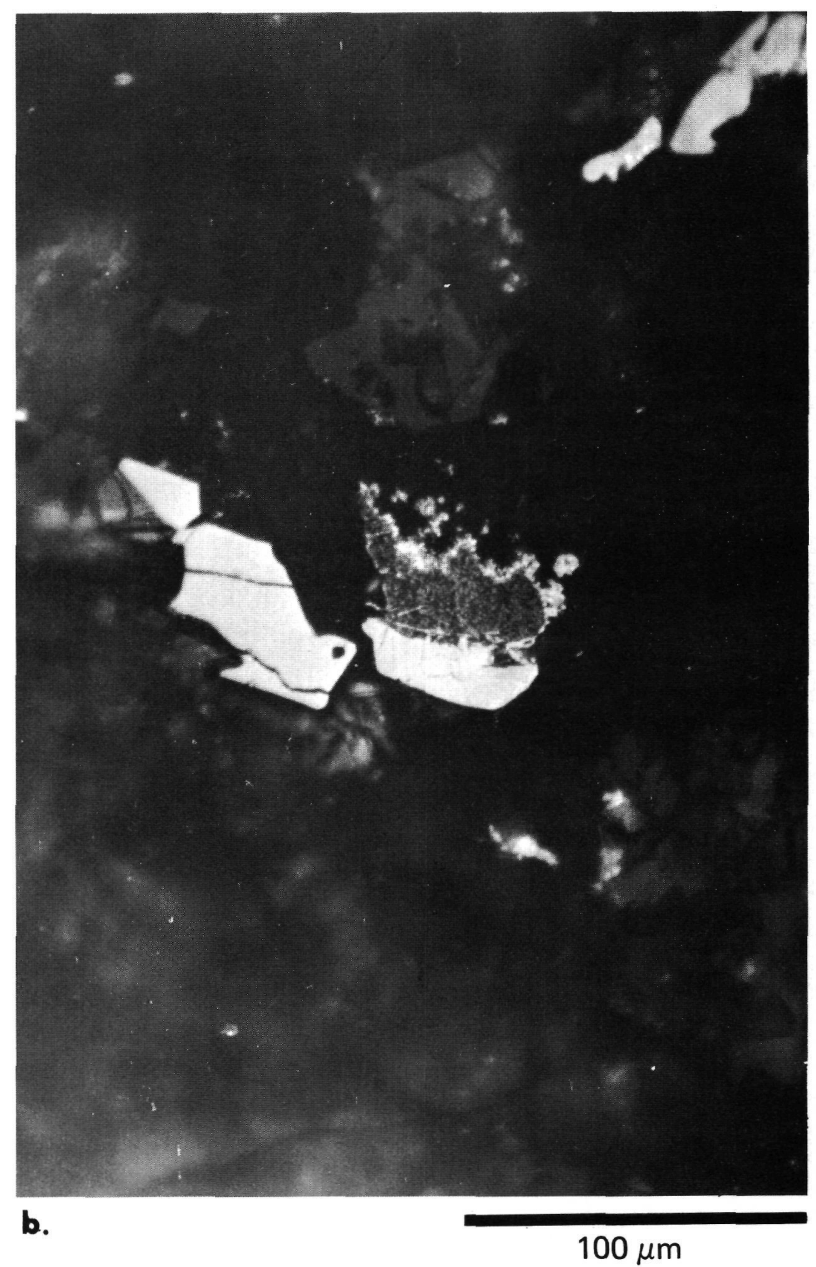

Figure 7b. The same grain with magnetic colloid shows a sharp separation in a magnetic and nonmagnetic part. This fact is a consequence of maghemitization.

TABLE 9

Ore Microscopic Description of Site 387 Basalts

\section{Ore Phases}

Sample

(Interval in $\mathrm{cm}$ )

General Petrography

Titanomagnetite

Ilmenite

Chromite

Other Phases

$\begin{array}{ll}\text { 50-1, 22-25 } & \begin{array}{l}\text { Coarser grained phyric basalt with } \\ \text { abundant plagioclase phenocrysts; }\end{array}\end{array}$
ophitic texture

$50-1,35-38$

Fine-grained amygdaloidal phyric basalt with bulky texture of plagioclase laths; slightly fewer phenocrysts than in $50-1,22-25 \mathrm{~cm}$

\section{$50-1,98-101$ \\ Fine-grained phyric basalt with large plagioclase phenocrysts; ophitic texture}

$50-2,30-33$

$50-2,134-137$
Fine-grained amygdaloidal phyric basalt with varying texture

Coarser grained amygdaloidal phyric basalt with ophitic texture
Large skeletal and small anhedral to subhedral grains; large grains; large grains are fringed by a fine second generation; most grains with volume change cracks, but no other indication of oxidation

Anhedral to subhedral grains from relatively large down to the limit of visibility; large grains show cracks with volume change, and small fringes of extremely fine grained second generation

Extremely small skeletal grains

Extremely fine anhedral to skeletal grains

Small skeletal grains sometimes bordered by sulfide grains
Not observed

Not observed

Small sulfide grain
Not observed

Not observed

Rare small isolated laths
Rare large euhedral grains with rims of titanomagnetite

Not observed

Not observed

Not observed
Small sulfide grains

Small sulfide grains

Tiny sulfide grains

Small sulfide grains 
rocks appears to be a chemical remanence acquired at some time after the emplacement of the rock. In this context, it is interesting to note that during the Tertiary the paleomagnetic pole of the North American plate was very close to the present North Pole.

\section{Site 386}

The samples show low-temperature oxidation of the titanomagnetites. At Site 368 the measured magnetization inclination values (mean $57.1^{\circ}$ ) are also much steeper than the expected inclination of $36.3^{\circ}$ for the Cretaceous. The present dipole field inclination of $50.4^{\circ}$ compares better with the measured values, which again suggests the buildup of a later chemical magnetization due to alteration of the magnetic minerals.

For Sample 66, CC (3), however, rock magnetic data do not support this conclusion as clearly as for the other samples.

\section{Site 387}

The situation here is more or less the same as in previous cases. The magnetic titanomagnetites have been altered by low-temperature oxidation.

The expected Cretaceous field inclination at Site 387 of $39.6^{\circ}$ is much shallower than the measured inclinations (mean $58.8^{\circ}$ ), which is close to the present magnetic dipole field inclination $\left(51.7^{\circ}\right)$.

In agreement with the rock magnetic data, the measured magnetization is also interpreted as a chemical remanent magnetization that has been built up over an extended period long after initial emplacement of the rocks. The original thermoremanent magnetization of the rocks has most likely been destroyed by low-temperature oxidation of the titanomagnetites.

\section{ACKNOWLEDGMENTS}

This study is a combined contribution of the Institut furr Allgemeine und Angewandte Geophysik, of the Institut für
Allgemeine und Angewandte Geologie, both Ludwig-Maximilians Universität, München, and of the Institut fur Geophysik, Ruhr-Universität, Bochum. We thank Prof. Dr. G. Angenheister, Prof. Dr. D. Klemm, and Prof. Dr. H. Baule for generously making available the facilities of the above named institutions and for their support throughout the study. The manuscript was reviewed by D. Kent and P. Vogt. The financial support of the Deutsche Forschungsgemeinschaft is gratefully acknowledged.

\section{REFERENCES}

Ade-Hall, J. M., 1974. Strong field magnetic properties of basalts from DSDP Leg 26. In Davies, T. A., Luyendyk, B., et al., Initial Reports of the Deep Sea Drilling Project, v. 26: Washington (U.S. Government Printing Office), p. 529-532.

Ade-Hall, J. M., Fink, L. K., and Johnson, H. P., 1976. Petrography of opaque minerals, Leg 34. In Hart, J. R., Yeats, R. S., et al., Initial Reports of the Deep Sea Drilling Project, v. 34: Washington (U.S. Government Printing Office), p. 349-362.

Bleil, U. and Petersen, N., 1977. Magnetic properties of basement rocks, Leg 37, Site 332. In Aumento, F., Melson, W. G., et al., Initial Reports of the Deep Sea Drilling Project, v. 37: Washington (U.S. Government Printing Office), p. $446-456$.

Grommé, C. S., Wright, T. L., and Peck, D. L., 1969. Magnetic properties and oxidation of iron-titanium oxide minerals in Alae and Makaopuhi lava lakes, Hawaii: J. Geophys. Res., v. 74, p. 5277-5293.

Kent, D. V. and Opdyke, N. D., 1976. Paleomagnetism and magnetic properties of igneous rock samples-Leg 38 In Talwani, M., Udintsev, G., et al., Initial Reports of the Deep Sea Drilling Project, Supplement to Volumes 38, 39, 40, and 41: Washington (U.S. Government Printing Office), p. 3-8.

McElhinny, M. W., 1973. Paleomagnetism and plate tectonics. Cambridge (Cambridge University Press).

Watkins, N. D. and Haggerty, S. E., 1967. Primary oxidation variation and petrogenesis in a single lava: Contrib. Mineral. Petrol., v. 15, p. 251-271. 